\title{
Facial nerve anastomosis in the mastoid portion using a cable graft. Case report
}

\section{Zespolenie nerwu twarzowego przeszzzepem kablowym w odcinku sutkowym. Opis przypadku}

Przemystaw Kunert, Marcin Skawiński, Andrzej Marchel

Katedra i Klinika Neurochirurgii, Warszawski Uniwersytet Medyczny

Neurologia i Neurochirurgia Polska 2011; 45, 5: 505-509

\begin{abstract}
We describe a case of a 52-year-old woman in whom surgery for two tumours located in the cerebellar hemisphere and in the posterior petrous bone was complicated by interruption of the facial nerve (CN VII). During the same procedure, anastomosis of CN VII, using a cable graft harvested from the great auricular nerve, was performed. Seven months later the first signs of reinnervation of the facial muscles were noticed. Two and a half years after surgery, CN VII function was assessed as grade II/III according to the House-Brackmann scale. The authors emphasize the significance of immediate repair of CN VII in modern skull base surgery but also the importance of a patient's self-training to obtain the best functional outcome of the facial reanimation. Reconstruction using the great auricular nerve has two significant advantages: first, the patient avoids further procedures for nerve repair, and second, the harvested nerve is located in direct proximity to the operation area.
\end{abstract}

Key words: facial nerve palsy, great auricular nerve, cable graft.

\section{Streszczenie}

W pracy opisano przypadek 52-letniej kobiety, u której operacja jednoczesnego usunięcia dwóch guzów zlokalizowanych w móżdżku i piramidzie kości skroniowej była powikłana przerwaniem ciągłości nerwu twarzowego. W czasie tego samego zabiegu wykonano zespolenie nerwu VII za pomocą przeszczepu kablowego pobranego z nerwu usznego wielkiego. Po 7 miesiącach pojawiły się pierwsze cechy reinerwacji mięśni twarzy. W późniejszym przebiegu, wraz ze stosowaną samodzielną rehabilitacją twarzy przy lustrze, obserwowano dalszą powolną poprawę. Po ponad 2,5 roku od operacji czynność nerwu VII oceniana jest na II/III stopień w skali House'a-Brackmanna. Autorzy podkreślają w pracy rolę śródoperacyjnych zespoleń nerwu VII we współczesnej chirurgii podstawy czaszki oraz konieczność samodzielnej pracy pacjenta dla osiągnięcia dobrego efektu reanimacji twarzy. Uzyskany dobry wynik regeneracji nerwu VII zachęca do częstszego wykorzystania przypomnianej tu techniki. Rekonstrukcja tym sposobem ma dwie istotne zalety: po pierwsze pacjent unika dodatkowych procedur chirurgicznych w celu naprawy nerwu VII, po drugie nerw pobierany do zespolenia znajduje się w bezpośrednim sąsiedztwie pola operacyjnego.

Słowa kluczowe: porażenie nerwu twarzowego, nerw uszny wielki, przeszczep kablowy.

Correspondence address: Przemysław Kunert, Katedra i Klinika Neurochirurgii, Warszawski Uniwersytet Medyczny, ul. Banacha 1 A, 02-097 Warszawa, fax +48226583653, e-mail: pkunert@wp.pl

Received: 25.01.2011; accepted: 4.05.2011 


\section{Introduction}

A method of choice in the case of damage to the facial nerve (CN VII) during surgery for tumours involving the cerebellopontine angle or pyramid of the temporal bone is direct end-to-end anastomosis of the nerve or, if a section of the nerve is missing, anastomosis using a cable graft. The 'loco operationis' anastomosis of the nerve yields better clinical results than secondary anastomoses with other motor nerves $[1,2]$. The sural nerve is most often used for various cable grafts, due to a known procedure for harvesting, its significant length and the number of bundles. Nerves which are less often used for that purpose are the supraclavicular nerve, lateral femoral cutaneous nerve, lesser internal cutaneous and lateral nerves and the great auricular nerve $[1,3]$.

The authors describe a case of a patient in whom surgery to remove two tumours of the cerebellum and pyramid was complicated with disruption of the CN VII. The aim of this paper is to present possibilities for treatment of that complication with a cable graft from the great auricular nerve, and to describe the surgical anatomy of that nerve.

\section{Case report}

A 52-year-old woman with von Hippel-Lindau disease, confirmed with genetic tests, was admitted due to a tumour of the left cerebellar hemisphere and re-growth of an endolymphatic sac tumour. Eight years earlier, at the Otolaryngology Department, the patient had surgery for an endolymphatic sac tumour located in the pyramid of the left temporal bone, which manifested itself by left-sided deafness. A few months before the present hospitalization, the patient underwent surgery for the removal of two tumours in the left kidney.

On admission the patient was in good general condition, with persistent left-sided deafness. During the neurological examination, a deviation to the left side when walking was additionally noted.

In the MRI examination, an increase of previously asymptomatic tumour of the left cerebellar hemisphere and a re-growth of the endolymphatic sac tumour were seen. Considering the basic disease, it was suspected that the cerebellar tumour was a haemangioblastoma and, due to the lack of clinical symptoms, the patient was not previously qualified for surgery. On this occasion, due to an increase in the size to $23 \mathrm{~mm} \times 14 \mathrm{~mm} \times 13 \mathrm{~mm}$, and occurrence of headaches and cerebellar syndrome, the patient was offered surgical treatment.

\section{Surgery}

Under general anaesthesia, in supine position with head turned to the right, left retrosigmoid craniotomy and presigmoid translabyrinthine approach were performed. While making the presigmoid approach in the vicinity of a scar from previous surgery, the CN VII was damaged in its mastoid part. The regrown endolymphatic sac tumour was removed first and then the cerebellar tumour. The last one macroscopically corresponded to haemangioblastoma. Following haemostasis and suturing of the dura mater, anastomosis of CN VII was started. Inspection of the damaged area showed that direct end-to-end anastomosis was not possible. In that case, a portion of about $10 \mathrm{~mm}$ of the great auricular nerve was harvested. Then, using that fragment as a cable graft, anastomosis of CN VII was performed by suturing both places of nerve stump connections with $8 / 0$ sutures. Good matching of stump end surfaces and anastomosis without tension were achieved. Places of connection were additionally strengthened by covering them with tissue glue. The bone flap was replaced and reconstruction of the mastoid process was done using bone chips, fat and tissue glue. The wound was closed in layers.

Following the surgery, a gold plate was implanted, loading the upper lid of the left eye, and the patient was trained in individual manual stimulation of facial muscles. The patient was discharged home in generally good condition, with facial nerve palsy, left-sided deafness and with gradual withdrawal of the cerebellar syndrome. The histopathological examination confirmed suspected types of removed tumours. Seven months after the surgery, the first symptoms of muscle reinnervation in the area of the left mouth corner appeared. During an examination after 21 months a satisfactory recovery of the nerve function was found, i.e., facial symmetry at rest and strong closing of the left eyelids (Fig. 1A). The gold plate was removed and the patient was encouraged to perform mimic exercises in front of a mirror. During the last examination, 32 months after the surgery, further improvement of the CN VII function was observed, near House-Brackmann grade II, in the middle and bottom part of the face (Figs. 1B-D).

\section{Discussion}

In the case of disruption of the CN VII during removal of a tumour, an attempt at its end-to-end anastomosis, directly or with a cable graft, should be made. From 


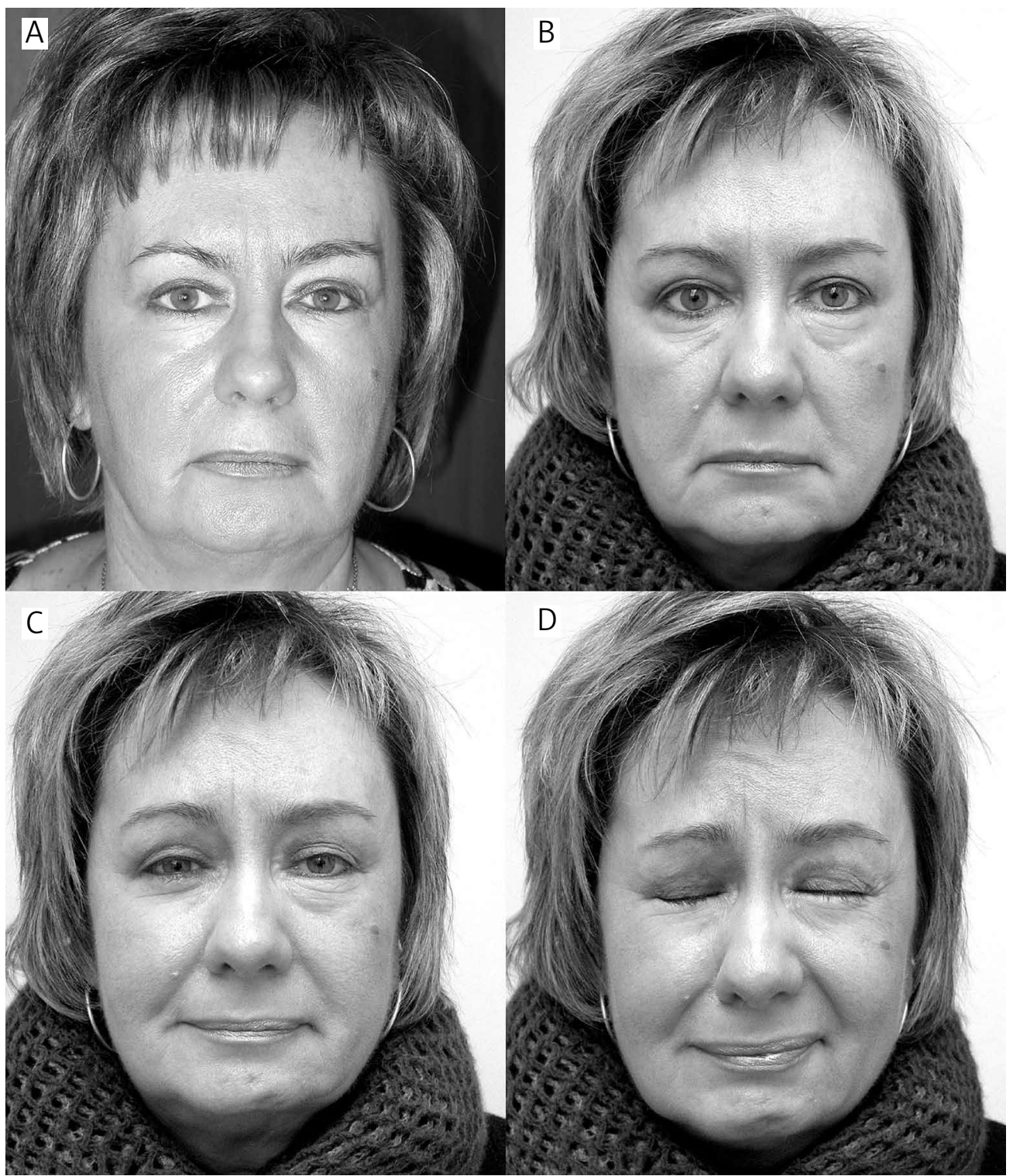

Fig. 1. Photographs of the patient, showing the late postoperative outcome. A) Face at rest 21 months after left-sided anastomosis. B) Face at rest 32 months after surgery. Note the more pronounced nasolabial fold on the left. ( and D) Voluntary movements and eye closure

a physiological point of view it is the best way of repairing the CN VII, in contrast to anastomoses with other cranial nerves. It gives a chance for recovering the most natural control over facial muscles, including emotions-related function. Despite theoretical advantages of anastomoses of that type, a treatment result exceeding House-Brackmann grade III is rarely achieved [4,5]. An issue worth mentioning in this paper is some inadequacy of the House-Brackmann grading for assessment of patients after CN VII anastomoses, as functional recovery usually varies in different levels of the face [5].
Typically, it is the worst in the area of the frontal branches, and that is also confirmed by the present case.

In cases where there is no possibility for direct anastomosis, a simultaneous cable graft from other nerves should be considered [5-8]. In the series of Bacciu et al., treatment results were evaluated for 33 patients after a cable graft. Satisfactory results were achieved in $3 / 4$ of the patients, regardless of whether the graft was made with micro-sutures or tissue glue [4]. Use of glue simplifies and shortens the procedure, and does not cause additional traumatisation to the nerve [9]. On the other 
hand, suturing facilitates more precise connection of the stumps. Gidley et al. used the cable graft beginning even at the brainstem itself, and evaluated the results using their own grading system. In $92 \%$ (23/25) of patients a recovery of CN VII function was observed, and the closer to the brainstem the graft was begun, the worse the results seemed to be (statistically insignificant difference) [5]. Samii, on the other hand, described the use of a cable graft to supplement missing bundles of the CN VII in case of its partial damage, i.e., when only part of the facial nerve thickness was damaged [10].

In the case described by us, the patient had surgery for a cerebellar haemangioblastoma and a regrowth of an endolymphatic sac tumour in the course of von HippelLindau disease. The endolymphatic sac tumour is a rare neoplasm and due to its specific location, damage to CN VII during its removal is described relatively often $[11,12]$. To supplement a missing CN VII portion, we used the great auricular nerve. The sural nerve is more often used for that purpose [7], due to a better known procedure for collecting and a larger number of fibres. In our opinion, the harvested section of the great auricular nerve was of a diameter similar to the facial nerve and very good matching of the stump thicknesses was achieved. May emphasised that the great auricular nerve diameter is adequate for most CN VII anastomoses [3]. A technique for its collection, versus the sural nerve, is possibly less known amongst neurosurgeons. The great auricular nerve can be harvested through a small extension of the incision used in operations for cerebellopontine angle and pyramid tumours; thus surgical anatomy of that nerve is worth describing. No need for preparation on the leg is an additional advantage, as that may be more difficult due to the patient's position during surgery.

The great auricular nerve is the largest cutaneous branch of the ansa cervicalis. It appears at Erb's point on the posterior edge of the sternocleidomastoid muscle, about $6-8 \mathrm{~cm}$ below the earlobe. Then it curves on the external surface of the sternocleidomastoid muscle and runs towards the head and the anterior edge of the sternocleidomastoid muscle. The nerve is embedded in the superficial cervical fascia and lies under the platysma. It runs almost parallel and slightly to the back of the external jugular vein. Its main trunk runs almost perpendicularly to and crosses in the middle the line connecting the angle of the mandible and the tip of the mastoid process [3].

Appearance of the first muscle contractions is only the first stage of facial reanimation. It is important to convince the patient about the need for daily mimic exercises in front of a mirror. They improve control over facial expression, and reduce asymmetry during spontaneous movements and emotional reactions. In the described patient, further improvement in the nerve function was observed between 21 and 32 months after surgery. The nerve function recovery may be very slow and further changes are observed even 2 years after surgery [2].

\section{Conclusions}

The good results of facial nerve reanimation obtained with the cable graft of the great auricular nerve encourage more frequent application of the technique described here. This method of reconstruction has two important advantages: first, the patient avoids additional surgical procedures for reanimation of the facial nerve, and second, the nerve harvested for anastomosis is located in the vicinity of the operation area.

\section{Acknowledgements}

We are very grateful to our patient for her cooperation and permission for publication of photographs.

\section{Disclosure}

Authors report no conflict of interest.

\section{References}

1. Humphrey C.D., Kriet J.D. Nerve repair and cable grafting for facial paralysis. Facial Plast Surg 2008; 24: 170-176.

2. Malik T.H., Kelly G., Ahmed A., et al. A comparison of surgical techniques used in dynamic reanimation of the paralyzed face. Otol Neurotol 2005; 26: 284-291.

3. May M. Nerve repair. In: May M., Schaitkin B. [eds.]. Facial paralysis: rehabilitation techniques. Thieme, New York 2003, pp. 21-59.

4. Bacciu A., Falcioni M., Pasanisi E., et al. Intracranial facial nerve grafting after removal of vestibular schwannoma. Am J Otolaryngol 2009; 30: 83-88.

5. Gidley P.W., Gantz B.J., Rubinstein J.T. Facial nerve grafts: from cerebellopontine angle and beyond. Am J Otol 1999; 20: 781-788.

6. Samii M. Neurosurgical aspects of the treatment of acoustic neurinoma with special consideration of the facial nerve. Laryngol Rhinol Otol (Stuttg) 1979; 58: 97-106.

7. Samii M. Facial nerve grafting in acoustic neurinoma. Clin Plast Surg 1984; 11: 221-225.

8. Kukwa A., Pietniczka M. Rekonstrukcja porażonej twarzy. Gazeta Stomatologiczna 1996; 3: 24-25.

9. Fisch U., Dobie R.A., Gmür A., et al. Intracranial facial nerve anastomosis. Am J Otol 1987; 8: 23-29.

10. Samii M., Koerbel A., Safavi-Abbasi S., et al. Using an end-toside interposed sural nerve graft for facial nerve reinforcement 
after vestibular schwannoma resection. Technical note. J Neurosurg 2006; 105: 920-923.

11. Doherty J.K., Yong M., Maceri D. Endolymphatic sac tumor: a report of 3 cases and discussion of management. Ear Nose Throat J 2007; 86: 30-35.

12. Bae C.W., Cho Y.H., Chung J.W., et al. Endolymphatic sac tumors: report of four cases. J Korean Neurosurg Soc 2008; 44: 268-272. 